\title{
Community Structure, Temporal and Spatial Changes of Epiphytic Algae on Three Different Submerged Macrophytes in a Shallow Lake
}

\author{
Burak Öterler* \\ Trakya University Faculty of Science Department of Biology. Balkan Campus, 22030
}

Received: 20 February 2017

Accepted: 5 April 2017

\begin{abstract}
The aim of this study was to determine the composition, biodiversity, and relative abundance of epiphytic algal species on three submerged aquatic plant species (the macrophytes Ceratophyllum demersum, Myriophyllum spicatum, and Potamogeton crispus) in Lake Gala in Lake Gala National Park, Turkey, and the associations of the observed relationships with environmental variables. The aquatic plants were collected at monthly intervals between March 2014 and November 2014, and epiphytic algae on the plants were identified. In total, 98, 74, and 66 taxa of epiphytic algae were identified on C. demersum, M. spicatum, and $P$. crispus, respectively. The species composition of the epiphytic algae on the three macrophyte species showed a statistically significant difference $(\mathrm{F}=7.07, \mathrm{p}<0.05)$. There was also a statistically significant difference in epiphytic algae species diversity, depending on the sampled month $(F=3.59, p<0.05)$. The mean species richness and species diversity on $C$. demersum was 33 and 1.546, respectively. On M. spicatum, the mean species richness and species diversity was 23 and 1.407, respectively. On P. crispus, the mean species richness was 19 , and the species diversity was 1.256 . The following species were the dominant epiphytic taxa in Gala Lake: Cocconeis placentula, Anabaena constricta, Gomphonema acuminatum, Oscillatoria limosa, Cymbella cistula, and Epithemia sorex. Although the species composition of the epiphytic algae was different, the diversity values were similar on all the macrophyte species.
\end{abstract}

Keywords: epiphytic algae, biodiversity, shallow lake, submerged macrophytes

\section{Introduction}

Macrophytes play an important role in the production of aquatic systems by recycling nutrients and increasing the biodiversity of aquatic organisms [1-2]. In shallow lakes, periphyton is particularly important, contributing to the nutrient cycle, energy flow, and food chain [3-

*e-mail: burakoterler@trakya.edu.tr
4]. Periphyton can also affect the rate of regeneration in aquatic habitats, support nutrient flow between pelagic and benthic areas, and regulate the amount of light and carbon sources in the water [5]. Epiphyton, which is contained within periphyton, is important for primary producers. Macrophytes have different morphological and physiological characteristics, and macrophyte diversity can affect species diversity and community structure of epiphytic species and periphyton communities [6]. Diatoms, cyanobacteria, and green algae are the main groups of benthic microalgae on macrophytes and 
constitute the greatest part of the epiphyton biomass [7-9].

Epiphytic algae are an important nutrient source for invertebrates and are important for assessing the trophic status of lakes [10]. They are widely used as indicators of water quality because they rapidly respond to hydrological and water quality changes [11]. The responses of these organisms over time to sources of pollution can be determined at the community level [12-13]. Waves can destroy the sediment structure, which in turn leads to reduction in biomass in the wave-zone [14-15]. The effect of waves in deep lakes decreases with increasing depth, but opposite cases can occur in shallow lakes [16]. As the characteristics of each aquatic ecosystem are different, the characteristics of the epiphytes are also different [17]. The aims of this study were: 1) to identify epiphytic algal species associated with three macrophyte species in Lake Gala, a shallow and eutrophic lake within Lake Gala National Park and an important part of the Meriç Delta, which is an international class A wetland, and 2) to identify environmental and hydrological factors affecting the substrate selection of these epiphytes.

\section{Material and Methods}

\section{Study Area}

Gala Lake, an alluvial dam lake, is located at $40^{\circ} 46^{\prime} 05^{\prime \prime} \mathrm{N}$ latitude and $26^{\circ} 10^{\prime} 59^{\prime \prime} \mathrm{E}$ longitudes and is connected to the Meriç River and Saroz Bay (Fig. 1). The lake has a depth of 50-200 cm [18-19]. The area, which was a nature reserve in 1991, was designated a Natural Protected Area in 1992 and a national park (Turkey's $\left.36^{\text {th }}\right)$ in 2005. The lake is located on one of the two most important bird migration routes in the western Palaearctic region. The lake is feed by the Meriç River, which is surrounded by rice fields. The release of irrigation water from rice farming areas into Gala Lake has resulted in chemical fertilizers and pesticides entering the lake and placing it under permanent anthropogenic-induced stress [20-21].

\section{Sampling}

From March 2014 to November 2014 samples were collected at monthly intervals, as winter months are not between March and November, from three submerged macrophyte species (Ceratophyllum demersum L., Myriophyllum spicatum L., and Potamogeton crispus L.) that are dominant in Gala to determine the epiphytic algal composition of the lake. The macrophytes were harvested from the sampling sites using quadrats of $1 \mathrm{~m}^{2}$ in size in 3-20 replicates, according to standard heterogeneity. The macrophytes in the quadrats were counted. At least three macrophytes were cut above ground level or removed from the ground. They were then washed in $250 \mathrm{ml}$ of distilled water or scrubbed with a brush, and the epiphytic algae were collected. The water used to wash the macrophytes was divided into defined amounts and then subjected to chlorophyll- $a$ analysis to determine species composition and count their abundance. For the last purpose subsamples were preserved with mixtures of Lugol's solution and glycerol [22-23].

The washed macrophytes were placed in separate polyethylene bags for biometric analysis, transported to the laboratory, and stored at $4^{\circ} \mathrm{C}$. The number and density of submerged macrophytes per $1 \mathrm{~m}^{2}$ in the lake, number and density of epiphytic algae on the macrophytes, and chlorophyll- $a$ concentration of the epiphytic algae in the sampled material were determined [24-26]. In addition,

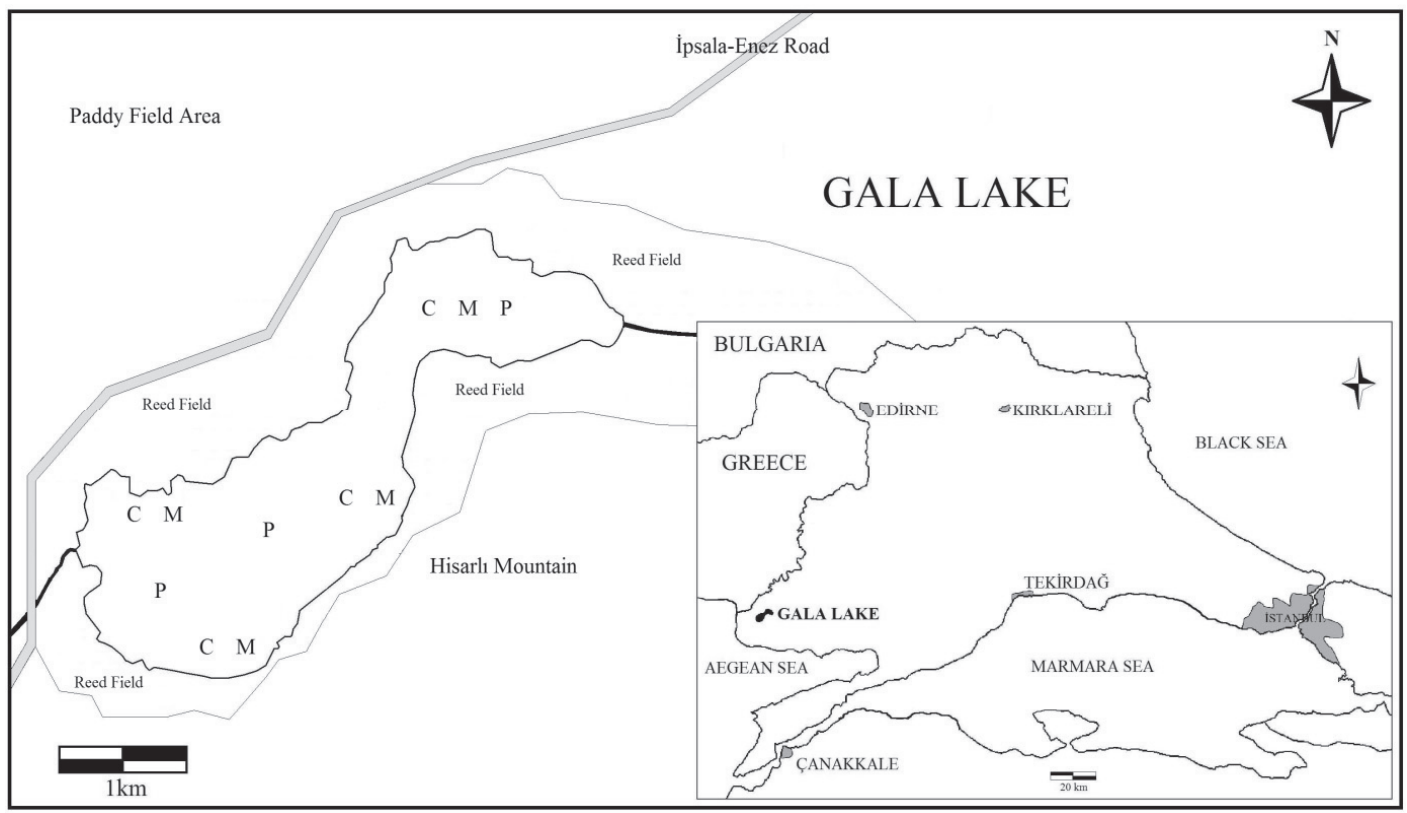

Fig. 1. The macrophyte distribution and sampling localities in Gala Lake (C: Ceratophyllum demersum, M: Myriophyllum spicatum, and P: Potamogeton crispus). 
Table 1. Some physicochemical parameters measured in Lake Gala during the study period.

\begin{tabular}{|c|c|c|c|c|c|c|c|c|}
\hline & Mar & Apr & May & Jun & Jul & Aug & Sep & Oct \\
\hline D.O. & 14.1 & $\mathbf{1 5 . 2}$ & 13.2 & 12.4 & 10.8 & $\mathbf{9 . 5}$ & 12.6 & 9.6 \\
\hline $\mathrm{NO}_{3}-\mathrm{N}$ & $\mathbf{7 . 2}$ & 4.04 & 1.8 & 4.4 & 1.19 & 1.88 & 3.32 & $\mathbf{0 . 0 1}$ \\
\hline $\mathrm{NO}_{2}-\mathrm{N}$ & 0.001 & 0.00 & 0.00 & 0.00 & 0.00 & 0.00 & 0.24 & 0.02 \\
\hline $\mathrm{o}^{-} \mathrm{PO}_{4}$ & $\mathbf{0 . 0 1}$ & $\mathbf{0 . 0 1}$ & $\mathbf{0 . 0 1}$ & $\mathbf{0 . 0 6}$ & 0.03 & 0.03 & 0.03 & $\mathbf{0 . 0 6}$ \\
\hline $\mathrm{pH}$ & $\mathbf{8 . 1}$ & 8.4 & $\mathbf{8 . 7}$ & 8.2 & 8.3 & 8.2 & 8.3 & 8.4 \\
\hline Con. & 145 & $\mathbf{1 4 3}$ & 187 & 163 & 270 & 250 & 310 & $\mathbf{3 2 0}$ \\
\hline Temp. & 14.8 & 17.8 & 19.3 & 26.7 & 27.6 & 25.6 & 23.6 & 19 \\
\hline Secchi & 48 & $\mathbf{4 6}$ & 56 & 47 & 76 & $\mathbf{9 1}$ & 26 & 51 \\
\hline Depth & $\mathbf{1 9 8}$ & 111 & 126 & 164 & 128 & 132 & 145 & $\mathbf{1 0 9}$ \\
\hline
\end{tabular}

D.O. (dissolved oxygen mg. $\mathrm{L}^{-1}$ ), $\mathrm{NO}_{3}-\mathrm{N}$ (nitrate-nitrogene mg. $\mathrm{L}^{-1}$ ), $\mathrm{NO}_{2}-\mathrm{N}$ (nitrite-nitrogene mg. $\mathrm{L}^{-1}$ ), o- $\mathrm{PO}_{4}$ (orthophosphate mg. $\mathrm{L}^{-1}$ ), Temp. (water temperature ${ }^{\circ} \mathrm{C}$ ) and Con. (electrical conductivity $\mu \mathrm{S} \mathrm{cm}^{-1}$ ), Secchi (cm), Depth (cm)

sub-surface water samples were collected using a Ruttner water sampler to analyse the physico-chemical properties of the water column and changes in these properties during the study period.

\section{Analyses}

The samples were dried in oven at $85^{\circ} \mathrm{C}$ for $24 \mathrm{~h}$, and the dry mass of the macrophytes collected from the lake was then determined. To identify the epiphytic algae samples collected after washing the macrophytes in $250 \mathrm{ml}$ of distilled water, a light microscope was used, with the samples placed under temporary mounts. The samples used for determining the diatoms $(50 \mathrm{ml})$ were first washed in a 1:1 mixture of $\mathrm{H}_{2} \mathrm{SO}_{4}$ and $\mathrm{HNO}_{3}$ and purified with distilled water. Permanent preparations were obtained using Naphrax. An average of 600-800 valves were counted on each preparation, the number of frustules in a pre-determined length was determined, and species identification was done using an Olympus CX21 microscope [27]. Sub-samples (10-25 ml and $50 \mathrm{ml}$ ) were also prepared, precipitated according to the Utermöhl method, and an inverted microscope (Olympus CK2 series) was used for organism counting and calculations [28].

Algal identification was done at $1000 \times$ magnification under immersion oil according to established methods [29-34]. All the identified species were checked in algaebase [35]. Chlorophyll- $a$ analysis was made according to Nush (using a Cecil 5502 instrument) [36].

Water temperature, $\mathrm{pH}$, dissolved oxygen, and conductivity values were measured at the sampling sites using portable equipment and probes (LovibondSensoDirect). Water transparency was measured at the sampling sites using a Secchi Disc. Nitrate nitrogene $\left(\mathrm{NO}_{3}-\mathrm{N}\right)$, Nitrite nitrogene $\left(\mathrm{NO}_{2}-\mathrm{N}\right)$, and orthophosphate $\left(\mathrm{o}-\mathrm{PO}_{4}\right)$ values were measured in the laboratory in accordance with APHA-AWWA-WPCF methods [37].

Species density in $\mathrm{cm}^{2}$ was calculated according to the method of Ros et al. by finding the surface area of macrophytes in which epiphytic samples were collected [38-39]. Biovolume calculations were done according to the methods of Hillebrand et al. and Sun and Lui [40-41]. The biovolume value of each species was mathematically determined, and the results were given in $\mathrm{mm}^{3} . \mathrm{cm}^{-2}$. The species diversity $\left(\mathrm{H}^{\prime}\right)$ and evenness index were calculated using equations developed by Shannon and Weaver. Pearson correlations between the environmental variables and species diversity, richness, and evenness were determined using SPSS 22.0 software [42]. To classify the algal composition on different macrophytes, cluster analyses was used and canonical correspondence analysis (CCA) was carried out using the XLSTAT-ADA statistical package [43]. CCA was carried out on the lognormal transformed abundance data to determine the relationships between the algae, environmental variables, and the sampling period.

\section{Results}

\section{Environmental Variables}

During the study period, the highest temperature was $27.6^{\circ} \mathrm{C}$, and the lowest was $14.8^{\circ} \mathrm{C}$. The highest $\mathrm{pH}$ was 8.7 and the lowest was 8.1 . The highest and lowest dissolved oxygen levels were $15.2 \mathrm{mg} \cdot \mathrm{L}^{-1}$ and $9.5 \mathrm{mg} . \mathrm{L}^{-1}$, respectively. The level of $\mathrm{NO}_{3}-\mathrm{N}$ varied from $0.01 \mathrm{mg} . \mathrm{L}^{-1}$ to $7.2 \mathrm{mg} . \mathrm{L}^{-1}$, and conductivity varied from $143 \mu \mathrm{S} . \mathrm{cm}^{-1}$ to $320 \mu \mathrm{S} . \mathrm{cm}^{-1}$ (Table 1). Spearman's correlation analysis revealed a direct correlation between the number of epiphytic organisms and water temperature and turbidity $(r=0.85, p<0.01 ; r=0.78, p<0.01$, respectively). 


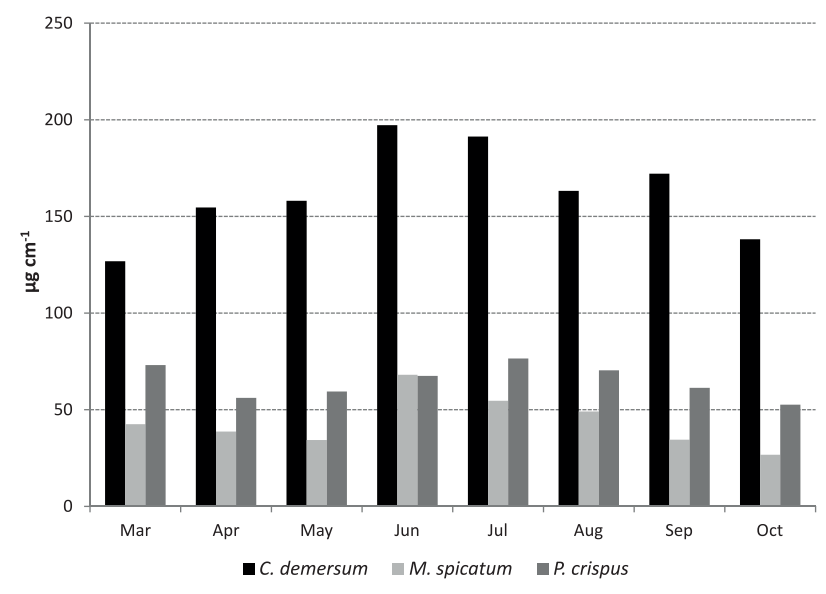

Fig. 2. Distributions of epiphytic chlorophyll-a concentrations on three macrophytes in Lake Gala.

The depth of the lake during the study was $109-200 \mathrm{~cm}$, and the Secchi disc visibility was $29-76.2 \mathrm{~cm}$. The water temperature showed a positive correlation with conductivity $(r=0.77, p<0.05)$, and dissolved oxygen showed a negative correlation with temperature $(r=-0.73, p<0.05)$ and $\mathrm{NO}_{3}{ }^{-} \mathrm{N}(r=-0.65$, $p<0.05)$. $\quad \mathrm{NO}_{3}{ }^{-} \mathrm{N}$ concentrations were significantly correlated with dissolved oxygen $(r=0.81, p<0.01)$ and Secchi disk transparency $(r=0.71, p<0.01)$.

The highest chlorophyll- $a$ concentration of epiphytic algae was on $C$. demersum in June $\left(197.2 \mu \mathrm{g} . \mathrm{cm}^{-1}\right)$, and the lowest amount was recorded on P. crispus in September (26.7 $\left.\mu \mathrm{g} . \mathrm{cm}^{-1}\right)$, as shown in Fig. 2.

\section{Macrophyte Abundance in Lake Gala}

During the study period, the average numbers of $C$. demersum, $M$. spicatum, and $P$. crispus per square meter were 24,21 , and 7 , respectively (Fig. 3 ).

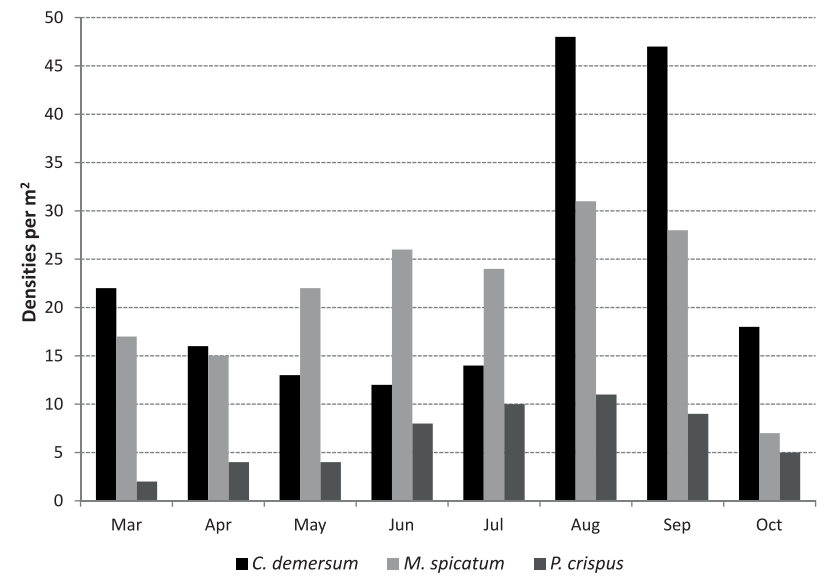

Fig. 3. Submerged macrophyte distribution in Lake Gala.

\section{Epiphytic Algal Composition}

In total, 131 taxa belonging to epiphytic algae were recorded in the lake. Bacillariophyta was the most abundant group ( $n=66$ taxa), followed by Chlorophyta ( $n=31$ taxa), Cyanophyta ( $n=19$ taxa), Euglenophyta ( $n=8$ taxa), Charophyta $(n=4$ taxa), Miozoa $(n=2$ taxa), and Cryptophyta ( $n=1$ taxon). When the epiphytonforming algae on the macrophytes were considered, the most algae-rich macrophyte species was $C$. demersum, with 98 taxa, followed by $M$. spicatum $(n=74$ taxa) and $P$. crispus $(n=66$ taxa), as shown in Table 2 .

When the entire sampling period considered Cocconeis placentula, it represented $12.25 \%$ of the total average relative biovolume and was the dominant organism on $C$. demersum. This was followed by Anabaena constricta (8.08\%), Encyonema silesiacum (7.28\%), and Oscillatoria sancta (4.95\%). Analysis of the relative biovolume revealed that Cymatopleura solea (9.98\%), C. placentula (8.90\%), Gomphonema acuminatum (8.38\%), A. constricta (7.94\%), Gomphonema affine $(7.51 \%)$, and Melosira varians $(7.25 \%)$ were the dominant organisms on $M$. spicatum. The same analysis revealed that $C$. placentula (12.89\%), Gomphonema parvulum (10.68\%), Oscillatoria limosa (10.19\%), A. constricta (9.01\%), Cymbella cistula (8.35\%), and G. acuminatum $(8.18 \%)$ were the dominant taxa on P. crispus (Figs 4(a-c)).

During the sampling period, the highest relative abundance of $C$. placentula was recorded on C. demersum. The relative biovolume of $C$. placentula was over $10 \%$ in all the sampled months. The highest relative biovolumes of O. sancta were recorded in August and October (11.5\% and $11.4 \%$, respectively). The highest relative biovolumes of A. constricta occurred in August (9.2\%), September $(9.7 \%)$, and October $(11.3 \%)$. The highest relative biovolume of Stauridium tetras was recorded in October $(11.3 \%)$. Since this species was only at highest value in October and was found at very low numbers during sampling periods except for October, it wasn't among the dominant organisms in the lake.

When the epiphytic algae on $M$. spicatum were considered with respect to the period in which they were most abundant, $C$. solea and G. acuminatum appeared to be common in spring months, $C$. placentula, $M$. varians, and Epithemia sorex seemed to be common in summer and autumn months, and $S$. tetras seemed to be common in autumn months. Among the epiphytic algae on P. crispus, the relative biovolume of $C$. placentula was above $10 \%$ during the entire sampling period, except in April. The highest relative biovolume values of $O$. limosa were found in March (12.4\%) and April (11.6\%), and those of $R$. abbreviata were recorded in March (16.8\%), April (12.8\%), and July (10.6\%). The highest relative biovolume values of $A$. constricta were recorded in August (11.4\%), September (15.1\%), and October (14.2\%), and those of E. sorex were found in September (19.3\%) and October (18.3\%). These taxa were also among the dominant organisms of the epiphytic community. 
Table 2. The macrophytes sampled and the epiphyton-forming algae determined in Lake Gala.

\begin{tabular}{|c|c|c|c|}
\hline & $\begin{array}{c}C . \\
\text { demersum }\end{array}$ & $\begin{array}{c}M . \\
\text { spicatum }\end{array}$ & $\begin{array}{c}P . \\
\text { crispus }\end{array}$ \\
\hline \multicolumn{4}{|c|}{ Cyanophyta } \\
\hline Anabaena sp. & $\mathbf{x}$ & $\mathbf{x}$ & $\mathbf{x}$ \\
\hline A. oscillarioides Bory. & $\mathbf{x}$ & $\mathbf{x}$ & $\mathbf{x}$ \\
\hline A. constricta (Szafer) Geitler & $\mathbf{x}$ & $\mathbf{x}$ & $\mathbf{x}$ \\
\hline Calothrix sp. & $\mathbf{x}$ & - & - \\
\hline $\begin{array}{c}\text { Chroococcus turgidus (Kütz.) } \\
\text { Näg. }\end{array}$ & $\mathbf{x}$ & - & $\mathbf{x}$ \\
\hline $\begin{array}{c}\text { Geitlerinema amphibium (Ag.) } \\
\text { Anag. }\end{array}$ & $\mathbf{x}$ & $\mathbf{x}$ & - \\
\hline Gleocapsa sp. & - & - & $\mathbf{x}$ \\
\hline $\begin{array}{l}\text { Komvophoron constrictum } \\
\text { (Szafer) Anag.\&Kom. }\end{array}$ & $\mathbf{x}$ & $\mathbf{x}$ & - \\
\hline K. crassum (Voz.) Anag.\&Kom. & $\mathbf{x}$ & - & - \\
\hline Lyngbya sp. & - & - & - \\
\hline $\begin{array}{c}\text { Merismopedia glauca (Ehren.) } \\
\text { Kütz. }\end{array}$ & $\mathbf{x}$ & $\mathbf{x}$ & $\mathbf{x}$ \\
\hline Oscillatoria limosa Ag. & $\mathbf{x}$ & - & $\mathbf{x}$ \\
\hline O. tenuis Ag. & - & $\mathbf{x}$ & $\mathbf{x}$ \\
\hline O. sancta Kütz. & $\mathbf{x}$ & - & - \\
\hline $\begin{array}{c}\text { Planktolyngbya } \\
\text { contorta (Lemm.)Anag.\& Kom. }\end{array}$ & $\mathbf{x}$ & - & - \\
\hline Planktothrix sp. & - & - & $\mathbf{x}$ \\
\hline Pseudoanabaena sp. & - & - & $\mathbf{x}$ \\
\hline P. limnetica Lemm. (Kom.) & $\mathbf{x}$ & - & - \\
\hline Spirulina sp. & $\mathbf{x}$ & - & - \\
\hline \multicolumn{4}{|c|}{ Chlorophyta } \\
\hline Actinastrum hantzschii Lag. & $\mathbf{x}$ & - & - \\
\hline Chlorella vulgaris Beyerinck & $\mathbf{x}$ & $\mathbf{x}$ & $\mathbf{x}$ \\
\hline $\begin{array}{c}\text { Cladophora glomerata (L.) } \\
\text { Kütz. }\end{array}$ & $\mathbf{x}$ & - & - \\
\hline Coelastrum astroideum De-Not & - & - & $\mathbf{x}$ \\
\hline Crucigenia tetrapedia West. & - & - & $\mathbf{x}$ \\
\hline Crucigeniella sp. & $\mathbf{x}$ & $\mathbf{x}$ & $\mathbf{x}$ \\
\hline $\begin{array}{c}\text { Desmodesmus magnus (Meyen) } \\
\text { Tsarenko }\end{array}$ & - & $\mathbf{x}$ & $\mathbf{x}$ \\
\hline Kirchneriella sp. & - & - & $\mathbf{x}$ \\
\hline Monoraphidium arcuatum Hind. & $\mathbf{x}$ & - & - \\
\hline M. contortum Kom-Legn. & $\mathbf{x}$ & $\mathbf{x}$ & $\mathbf{x}$ \\
\hline Oocystis sp & $\mathbf{x}$ & - & - \\
\hline O. parva West. & $\mathbf{x}$ & $\mathbf{x}$ & $\mathbf{x}$ \\
\hline Pediastrum duplex Meyen & $\mathbf{x}$ & $\mathbf{x}$ & - \\
\hline
\end{tabular}

Table 2. Continued.

\begin{tabular}{|c|c|c|c|}
\hline $\begin{array}{l}\text { Pseudopediastrum boryanum } \\
\text { (Turp.) Hegewald }\end{array}$ & $\mathbf{x}$ & - & - \\
\hline $\begin{array}{l}\text { Raphidocelis subcapitata } \\
\text { (Korsh.) Nygaard }\end{array}$ & $\mathbf{x}$ & - & $\mathbf{x}$ \\
\hline $\begin{array}{c}\text { Scenedesmus bijuga (Turp.) } \\
\text { Lagerheim }\end{array}$ & - & $\mathbf{x}$ & - \\
\hline S. obtusus Mey. & - & - & $\mathbf{x}$ \\
\hline S. quadricauda (Turp.) Breb. & $\mathbf{x}$ & $\mathbf{x}$ & $\mathbf{x}$ \\
\hline $\begin{array}{l}\text { Schroederia setigera (Schr.) } \\
\text { Lemm. }\end{array}$ & $\mathbf{x}$ & - & - \\
\hline S. spiralis (Printz) Korsh. & $\mathbf{x}$ & - & - \\
\hline $\begin{array}{c}\text { Stauridium tetras (Ehren.) } \\
\text { Hegewald }\end{array}$ & $\mathbf{x}$ & $\mathbf{x}$ & - \\
\hline $\begin{array}{l}\text { Stigeoclonium lubricum } \\
\text { (Dillwyn) Kütz. }\end{array}$ & $\mathbf{x}$ & - & - \\
\hline $\begin{array}{l}\text { Tetradesmus lagerheimii Wynne } \\
\text { \& Guiry }\end{array}$ & $\mathbf{x}$ & - & $\mathbf{x}$ \\
\hline T. obliquus (Turp.) Wynne & - & $\mathbf{x}$ & - \\
\hline Tetraedron caudatum Hansg. & - & $\mathbf{x}$ & $\mathbf{x}$ \\
\hline T. minimum Hansg. & $\mathbf{x}$ & - & $\mathbf{x}$ \\
\hline T. trigonum Hansg. & $\mathbf{x}$ & - & $\mathbf{x}$ \\
\hline Tetrastrum komarekii Hind. & - & - & $\mathbf{x}$ \\
\hline T. staugeniforme Lemm. & - & - & $\mathbf{x}$ \\
\hline T. triangulare (Chod.) Kom. & - & $\mathbf{x}$ & $\mathbf{x}$ \\
\hline $\begin{array}{l}\text { Ulothrix zonata (Weber\&Mohr) } \\
\text { Kütz. }\end{array}$ & $\mathbf{x}$ & - & - \\
\hline \multicolumn{4}{|c|}{ Charophyta } \\
\hline Closterium littorale Gay & $\mathbf{x}$ & - & - \\
\hline C. lunula Ehren. & $\mathbf{x}$ & $\mathbf{x}$ & $\mathbf{x}$ \\
\hline Cosmarium sp. & $\mathbf{x}$ & $\mathbf{x}$ & $\mathbf{x}$ \\
\hline Spirogyra maxima (Hass.) Witt. & $\mathbf{x}$ & - & - \\
\hline \multicolumn{4}{|c|}{ Miozoa } \\
\hline $\begin{array}{l}\text { Peridinium cinctum (Müller) } \\
\text { Ehren. }\end{array}$ & $\mathbf{x}$ & - & $\mathbf{x}$ \\
\hline $\begin{array}{c}\text { Gymnodinium helveticum } \\
\text { Penard }\end{array}$ & - & - & $\mathbf{x}$ \\
\hline \multicolumn{4}{|c|}{ Euglenophyta } \\
\hline $\begin{array}{c}\text { Euglena granulata (Klebs) } \\
\text { Schmitz }\end{array}$ & $\mathbf{x}$ & $\mathbf{x}$ & $\mathbf{x}$ \\
\hline Lepocinclis radiata Chade & - & $\mathbf{x}$ & $\mathbf{x}$ \\
\hline L. texta (Duj.) Lemm. & - & $\mathbf{x}$ & $\mathbf{x}$ \\
\hline Phacus acuminatus Stokes & $\mathbf{x}$ & - & $\mathbf{x}$ \\
\hline $\begin{array}{c}\text { Trachelomonas armata (Ehren.) } \\
\text { Stein }\end{array}$ & $\mathbf{x}$ & - & $\mathbf{x}$ \\
\hline T. hispida (Perty) Stein & $\mathbf{x}$ & - & - \\
\hline T. minima Drezepolski & $\mathbf{x}$ & $\mathbf{x}$ & $\mathbf{x}$ \\
\hline T. volvocina (Ehren.) Ehren. & $\mathbf{x}$ & $\mathbf{x}$ & - \\
\hline
\end{tabular}


Table 2. Continued.

\begin{tabular}{|c|c|c|c|}
\hline \multicolumn{4}{|c|}{ Cryptophyta } \\
\hline Cryptomonas sp. & - & $\mathbf{x}$ & $\mathbf{x}$ \\
\hline \multicolumn{4}{|c|}{ Bacillariophyta } \\
\hline $\begin{array}{l}\text { Achnanthidium affine (Grun.) } \\
\text { Czarnecki }\end{array}$ & $\mathbf{x}$ & - & - \\
\hline $\begin{array}{c}\text { Achnanthes exiguum (Grun.) } \\
\text { Czarnecki }\end{array}$ & - & $\mathbf{x}$ & - \\
\hline Amphora ovalis (Kütz.) Kütz. & $\mathbf{x}$ & $\mathbf{x}$ & - \\
\hline Asterionella formosa Hass. & $\mathbf{x}$ & - & $\mathbf{x}$ \\
\hline $\begin{array}{l}\text { Brebissonia lanceolata (Ag.) } \\
\text { Mah.\&Reimer }\end{array}$ & $\mathbf{x}$ & $\mathbf{x}$ & $\mathbf{x}$ \\
\hline $\begin{array}{c}\text { Caloneis amphisbaena (Bory) } \\
\text { Cleve }\end{array}$ & $\mathbf{x}$ & $\mathbf{x}$ & - \\
\hline C. bacillum (Grun.) Cleve & $\mathbf{x}$ & - & - \\
\hline Cocconeis pediculus Ehren. & $\mathbf{x}$ & $\mathbf{x}$ & - \\
\hline C. placentula Ehren. & $\mathbf{x}$ & $\mathbf{x}$ & $\mathbf{x}$ \\
\hline $\begin{array}{c}\text { Craticula cuspidata (Kütz.) } \\
\text { Mann }\end{array}$ & $\mathbf{x}$ & $\mathbf{x}$ & $\mathbf{x}$ \\
\hline Cyclotella meneghiniana Kütz. & $\mathbf{x}$ & $\mathbf{x}$ & $\mathbf{x}$ \\
\hline C. radiosa (Grun.) Lemm. & $\mathbf{x}$ & $\mathbf{x}$ & $\mathbf{x}$ \\
\hline $\begin{array}{c}\text { Cymatopleura solea (Breb.) } \\
\text { Smith }\end{array}$ & $\mathbf{x}$ & $\mathbf{x}$ & - \\
\hline $\begin{array}{c}\text { Cymbella cistula (Hemprich) } \\
\text { Grun. }\end{array}$ & $\mathbf{x}$ & $\mathbf{x}$ & $\mathbf{x}$ \\
\hline $\begin{array}{c}\text { Entomoneis alata (Ehren.) } \\
\text { Ehren. }\end{array}$ & $\mathbf{x}$ & - & - \\
\hline Denticula kuetzingii Grun. & - & - & $\mathbf{x}$ \\
\hline $\begin{array}{l}\text { Diploneis didyma (Ehren.) } \\
\text { Ehren. }\end{array}$ & - & $\mathbf{x}$ & $\mathbf{x}$ \\
\hline $\begin{array}{c}\text { Encyonema silesiacum (Ble.) } \\
\text { Mann }\end{array}$ & $\mathbf{x}$ & - & - \\
\hline $\begin{array}{l}\text { Encyonopsis microcephala } \\
\text { (Grun.) Krammer }\end{array}$ & - & $\mathbf{x}$ & - \\
\hline E. minuta Kram.\&Reich. & $\mathbf{x}$ & - & - \\
\hline Epithemia sorex Kütz. & $\mathbf{x}$ & $\mathbf{x}$ & $\mathbf{x}$ \\
\hline E. turgida (Ehren.) Kütz. & - & $\mathbf{x}$ & $\mathbf{x}$ \\
\hline Fragilaria sp. & $\mathbf{x}$ & $\mathbf{x}$ & - \\
\hline F. capucina Desm. & $\mathbf{x}$ & - & - \\
\hline $\begin{array}{l}\text { Fragilaria construens (Ehren.) } \\
\text { Grun. }\end{array}$ & $\mathbf{x}$ & - & - \\
\hline $\begin{array}{l}\text { Fragilariforma virescens (Ralfs) } \\
\text { Williams\&Round }\end{array}$ & $\mathbf{x}$ & $\mathbf{x}$ & - \\
\hline $\begin{array}{c}\text { Gomphonema acuminatum } \\
\text { Ehren. }\end{array}$ & $\mathbf{x}$ & $\mathbf{x}$ & $\mathbf{x}$ \\
\hline G. affine Kütz. & - & - & $\mathbf{x}$ \\
\hline G. gracile Ehren. & $\mathbf{x}$ & $\mathbf{x}$ & - \\
\hline G. olivaceum (Horn.) Bréb. & $\mathbf{x}$ & $\mathbf{x}$ & - \\
\hline
\end{tabular}

Table 2. Continued.

\begin{tabular}{|c|c|c|c|}
\hline G. parvulum (Kütz.) Kütz & $\mathbf{x}$ & $\mathbf{x}$ & $\mathbf{x}$ \\
\hline Gyrosigma acuminatum (Kütz.) & $\mathbf{x}$ & $\mathbf{x}$ & - \\
\hline $\begin{array}{c}\text { Halamphora veneta (Kütz. } \\
\text { Levkov }\end{array}$ & $\mathbf{x}$ & $\mathbf{x}$ & - \\
\hline $\begin{array}{l}\text { Hippodonta capitata (Ehren.) } \\
\text { L.-Bert., Metz.\&Witk. }\end{array}$ & $\mathbf{x}$ & $\mathbf{x}$ & - \\
\hline Mastogloia smithii Grun. & $\mathbf{x}$ & $\mathbf{x}$ & - \\
\hline $\begin{array}{c}\text { Mayamaea atomus (Kütz.) } \\
\text { Lange-Bertalot }\end{array}$ & - & $\mathbf{x}$ & - \\
\hline Melosira varians Agardh & $\mathbf{x}$ & $\mathbf{x}$ & - \\
\hline Navicula cryptocephala Kütz & $\mathbf{x}$ & $\mathbf{x}$ & - \\
\hline N. lanceolata (Ag.) Kütz. & $\mathbf{x}$ & - & - \\
\hline N. radiosa Kütz. & $\mathbf{x}$ & $\mathbf{x}$ & - \\
\hline N. reinhardtii (Grun.) Grun. & $\mathbf{x}$ & - & - \\
\hline N. tripunctata (Müll.) Bory & $\mathbf{x}$ & $\mathbf{x}$ & $\mathbf{x}$ \\
\hline N. viridula (Kütz.) & $\mathbf{x}$ & $\mathbf{x}$ & $\mathbf{x}$ \\
\hline Nitzschia sp. & $\mathbf{x}$ & - & $\mathbf{x}$ \\
\hline N. acicularis Smith & $\mathbf{x}$ & $\mathbf{x}$ & $\mathbf{x}$ \\
\hline N. balcanica Hustedt & $\mathbf{x}$ & $\mathbf{x}$ & - \\
\hline N. capitellata Husted & - & - & $\mathbf{x}$ \\
\hline N. frustulum (Kütz.) Grun. & $\mathbf{x}$ & $\mathbf{x}$ & - \\
\hline N. linearis Smith. & $\mathbf{x}$ & $\mathbf{x}$ & - \\
\hline N. obtusa Smith & - & - & $\mathbf{x}$ \\
\hline N. palea (Kütz.) Smith & $\mathbf{x}$ & $\mathbf{x}$ & $\mathbf{x}$ \\
\hline N. perminuta (Grun.) Peraga. & - & $\mathbf{x}$ & $\mathbf{x}$ \\
\hline N. sigmoidea (Ehren.) Smith & $\mathbf{x}$ & $\mathbf{x}$ & - \\
\hline Pinnularia divergens Smith & - & $\mathbf{x}$ & - \\
\hline P. viridis (Nitzs.) Ehren. & - & $\mathbf{x}$ & - \\
\hline $\begin{array}{l}\text { Placoneis clementis (Grun.) } \\
\text { Cox }\end{array}$ & $\mathbf{x}$ & $\mathbf{x}$ & - \\
\hline P. elginensis (Greg.) Cox & $\mathbf{x}$ & - & $\mathbf{x}$ \\
\hline $\begin{array}{c}\text { Rhoicosphenia abbreviata (Ag.) } \\
\text { Lange-Bertalot }\end{array}$ & $\mathbf{x}$ & $\mathbf{x}$ & $\mathbf{x}$ \\
\hline Stauroneis anceps Ehren. & $\mathbf{x}$ & - & - \\
\hline $\begin{array}{c}\text { Stephanodiscus astraea (Ehr.) } \\
\text { Grun. }\end{array}$ & $\mathbf{x}$ & $\mathbf{x}$ & $\mathbf{x}$ \\
\hline Surirella ovalis Breb. & $\mathbf{x}$ & - & - \\
\hline $\begin{array}{c}\text { Tabellaria fenestrata (Lyng.) } \\
\text { Kütz. }\end{array}$ & $\mathbf{x}$ & $\mathbf{x}$ & $\mathbf{x}$ \\
\hline T. flocculosa (Roth) Kütz. & - & $\mathbf{x}$ & - \\
\hline Tryblionella sp. & $\mathbf{x}$ & - & - \\
\hline T. hungarica (Grun.) Frenguelli & $\mathbf{x}$ & $\mathbf{x}$ & $\mathbf{x}$ \\
\hline Ulnaria ulna (Nitzs.) Compère & $\mathbf{x}$ & - & - \\
\hline
\end{tabular}


Cluster analysis showed that the species composition of epiphytic algae on the three macrophyte species varied, with similar species of epiphytic algae found on $C$. demersum and P. crispus (67\%), but different species were found on M. spicatum (Fig. 5).

\section{Species Diversity and Richness of Epiphytic Algae}

Throughout the study period, high numbers of diatoms and blue-green algae were recorded. The maximum number of species $(n=41)$ was recorded in May on $C$. demersum, and the minimum number $(n=12)$ was recorded in April on P. crispus (Figs 6-8). The species diversity of epiphytic algae on the three macrophyte species sampled was significantly different $(F=7.07$, $p<0.05)$. There was also a significant difference in algal diversity, according to the sampling month $(F=3.59$, $p<0.05)$. The species diversity and species richness values for $C$. demersum, $M$. spicatum, and P. crispus were 1.546 and 33, 1.407 and 23, and 1.256 and 19, respectively.

\section{Canonical Correspondence Analysis}

CCA analysis was conducted to determine the association between the relative abundance of the epiphytic algae and environmental factors. The 18 dominant taxa in the epiphyton and the association of these taxa with seven environmental variables are listed in Fig. 6. According to the CCA biplot analysis, the eigenvalues of the first two axes were 0.79 and 0.41 , respectively. The first axis of CCA explained $16.39 \%$ of the total variance in species, and the second axis explained $53.42 \%$ of the total variance. On the three macrophyte species, C. placentula was placed near the origin of the ordination diagram. In the spring months, Geitlerinema amphibium and Gomphonema parvula showed a positive correlation with $\mathrm{pH}$, nitrite, and nitrate. In June and July, the relative abundance of Planktolyngbya contorta and G. acuminatum showed a positive correlation with light transmission. In August and September, the relative abundance of $A$. constricta and $E$. sorex displayed a positive correlation with conductivity, temperature, and o- $\mathrm{PO}_{4}$ (Fig. 9).

\section{Discussion}

In common with many shallow lakes, Gala is exposed to pressure from nearby agricultural activities [44-45]. Other than temperature, seasonal variations in the physical and chemical properties of the lake are primarily determined by irrigation channels connected to the lake for agricultural purposes $[19,46]$. The key role of nutrients in algal development is well known [47]. In Gala, the nutrient levels change constantly throughout the year as a result of the agricultural areas surrounding the lake. During the study period, the average environmental values did not reach eutrophication values. The $\mathrm{pH}$ was slightly alkaline. Although the dissolved oxygen level was high, it was not as high as that recorded in previous studies [48]. In the present study, the decrease in concentrations of both $\mathrm{NO}_{3}-\mathrm{N}$ and $\mathrm{o}-\mathrm{PO}_{4}$ may be attributed to dense macrophyte vegetation associated with periods of agricultural activity.

In this study, lake turbidity increased and light transmission decreased in accordance with the period of phytoplankton multiplication and wind. Therefore, in the spring months, especially in March and April, low epiphyton biovolumes and low species richness and
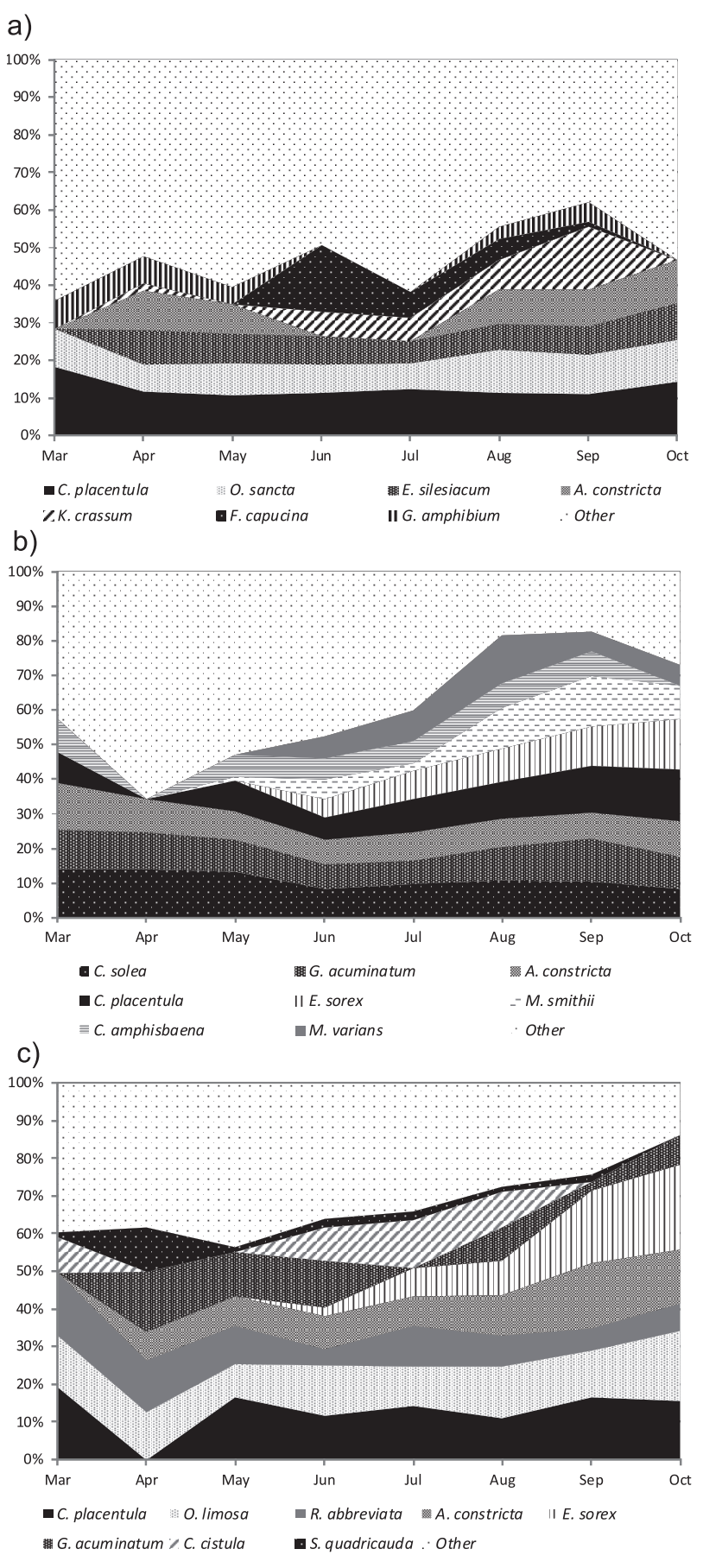

Fig. 4. Monthly distributions of the relative biovolume of the dominant epiphytic algae sampled on macrophytes in Lake Gala: a) C. demersum, b) M. spicatum, and c) P. crispus. 


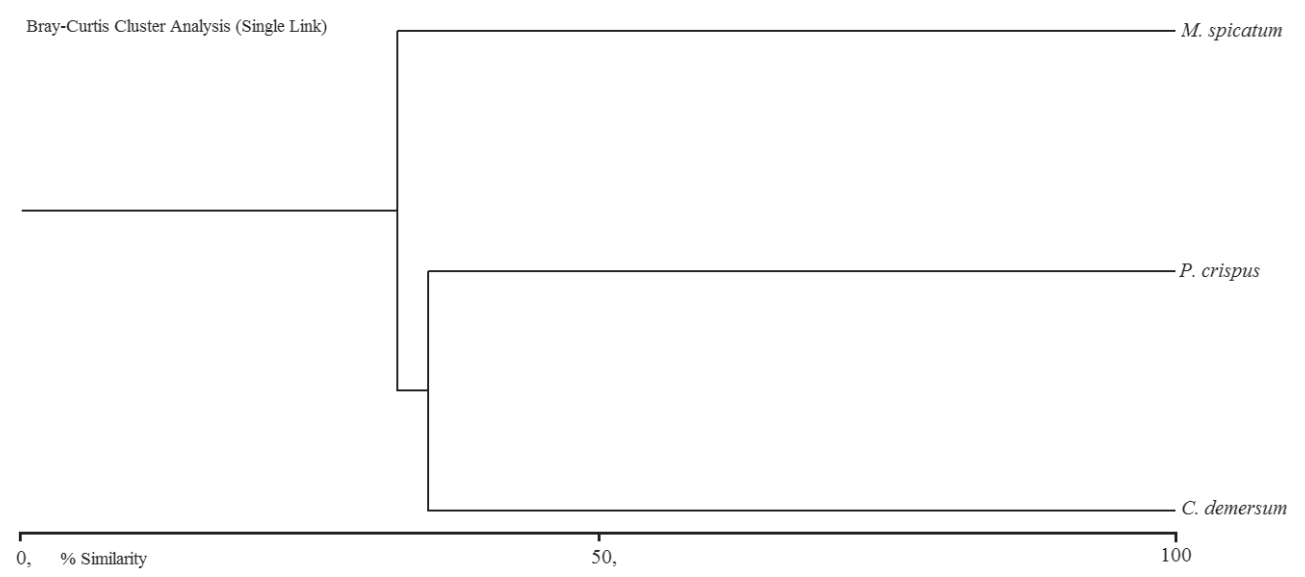

Fig. 5. Bray-Curtis similarity diagram of the epiphytic algae determined on sampled macrophytes in Lake Gala.

evenness were detected. In addition, the diversity index was lower. During the turbid-water period, phytoplankton overshadowing of the epiphytic community may have initially been pronounced. However, upon the development of submerged macrophyte stands between September and October, light conditions promoted epiphyte growth. As both the density of emergent macrophytes and submerged plant cover were low at all the sampling sites, shadowing likely had little influence on epiphytic growth. Similar results have been reported for similar lakes [49].

The depth of the macrophyte-dominated Gala was low during the study period. In lakes exposed to open and windy conditions, a high rate of turbidity and waves result in low Secchi disc visibility. These conditions produce a suitable environment for the development of diatoms [50]. Compared to environmental variables, attached diatoms appear to be more supplementary indicators that respond rapidly to environmental changes [51-52]. In Gala, in terms of the number of taxa, abundance, and biovolume, diatoms were the dominant group of epiphytic algae. This group was followed by cyanobacteria, with higher numbers in terms of the number of colonies and cells and number of species. Other studies of shallow

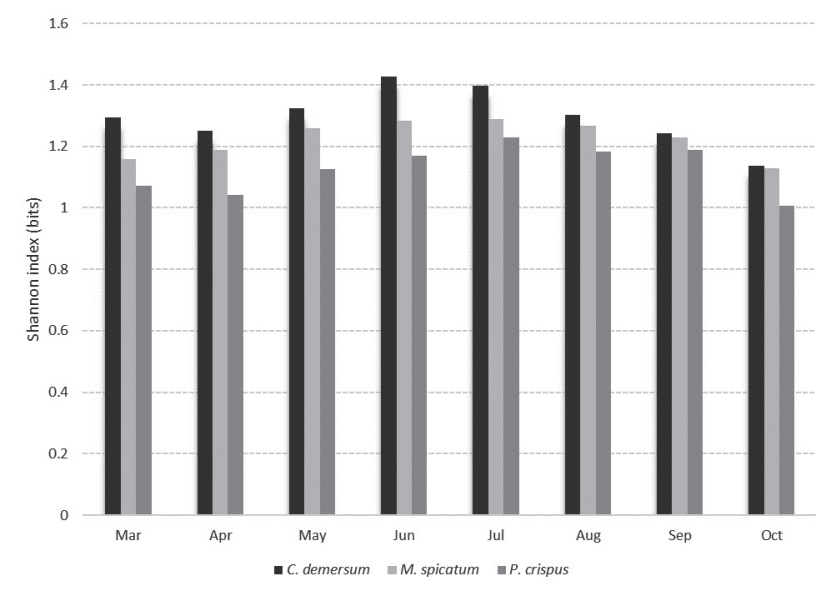

Fig. 6. Shannon diversity index $\left(\mathrm{H}^{\prime}\right)$ of epiphytic algae species of three submerged macrophytes during the study period. lakes reported similar findings $[13,53]$. The presence of high-order planktonic species in the epiphyton, especially on submerged macrophytes in shallow systems, such as Gala, is to be expected. As reported previously, there is a

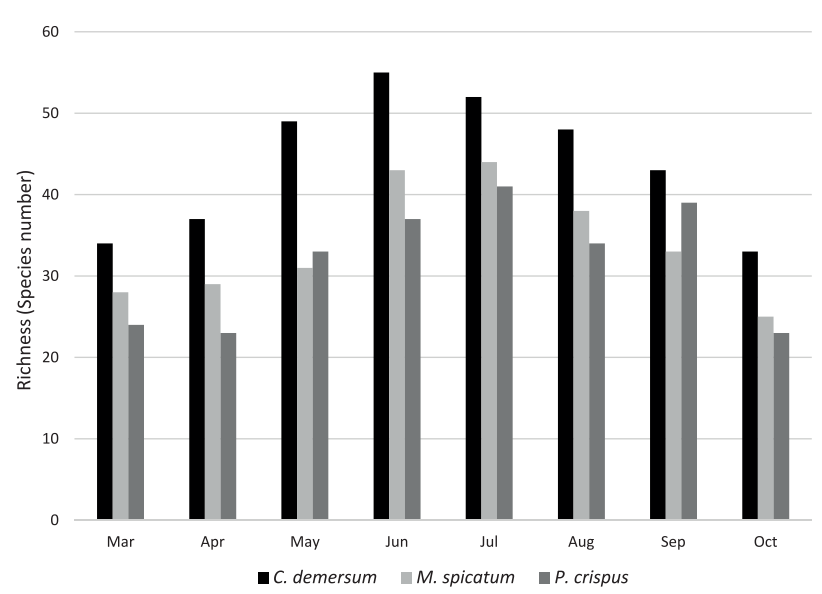

Fig. 7. Species richness of epiphytic algae species of three submerged macrophytes during the study period.

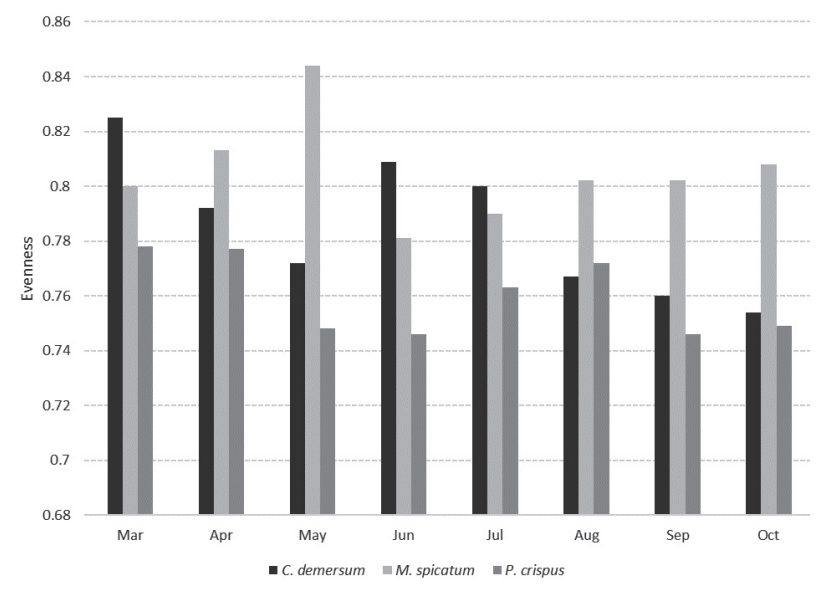

Fig. 8. Evenness index of epiphytic algae species of three submerged macrophytes during the study period. 


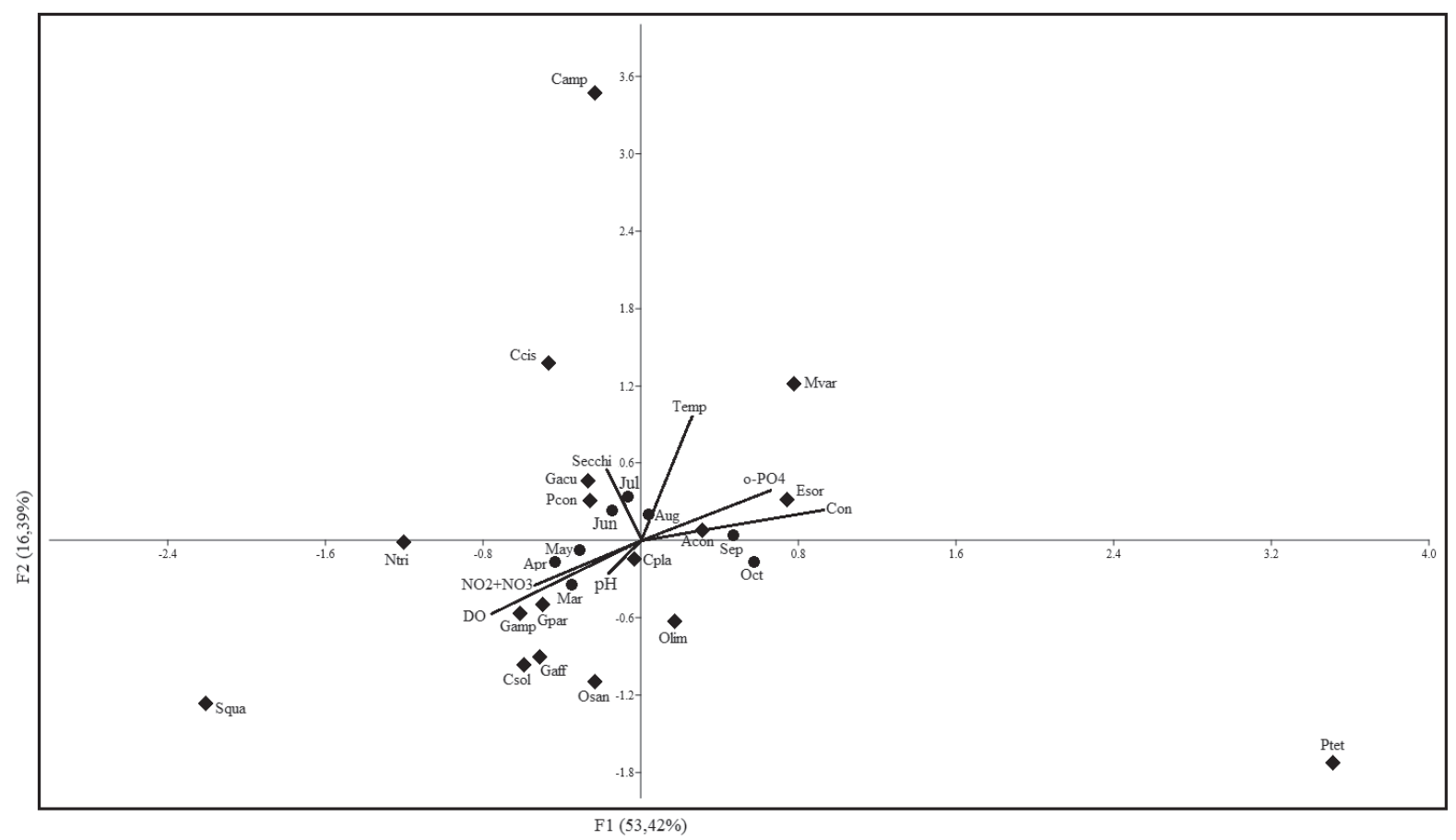

Fig. 9. Canonical correspondence analysis (CCA) results showing the sampling months, environmental variables and dominant taxa on three macrophytes. Environmental variables - DO: dissolved oxygen, $\mathrm{NO}_{2}+\mathrm{NO}_{3}$ : nitrite and nitrate, o- $\mathrm{PO}_{4}$ : orthophosphate, Con: conductivity, and Temp.: water temperature; epiphytic algal species - Acon: Anabaena constricta, Camp: Caloneis amphisbaena, Cpla: Cocconeis placentula, Csol: Cymatopleura solea, Ccis: Cymbella cistula, Esil: Encyonema silesiacum, Esor: Epithemia sorex, Gamp: Geitlerinema amphibium, Gacu: Gomphonema acuminatum, Gaff: Gomphonema affine, Gpar: Gomphonema parvulum, Mvar: Melosira varians, Ntri: Navicula tripunctata, Olim: Oscillatoria limosa, Osan: Oscillatoria sancta, Pcon: Planktolyngbya contorta, Squa: Scenedesmus quadricauda, and Stet: Stauridium tetras.

strong correlation between limnetic and benthic habitats due to the high proportions of mixture of the water column and resulting sediment re-suspension [54]. The high degree of species richness can be attributed to environmental and biological factors, such as host plant surface heterogeneity and nutrient concentrations [55].

As expected, the highest number of species and biovolumes of epiphytic algae were associated with C. demersum, the dominant macrophyte in the benthic stratum of Gala. Although higher numbers of epiphytic algal species and higher biovolumes were recorded on M. spicatum than on P. crispus, the chlorophyll-a concentration of epiphytic algae associated with M. spicatum was reduced as compared to P. crispus. This finding may be due to the dominance of diatoms on M. spicatum. However, as noted in previous studies, they could also be due to the presence of planktonic green algae and euglenoid on P. crispus $[20,50,57]$. Green algae attach to the substratum in a less coherent way than diatoms, and some only accompany the overgrowing community [6]. Thus, numbers of green algae may be increased in interstem water, resulting in higher values of chlorophyll- $a$ [49]. Representatives of this algal group are commonly unattached (e.g., due to waves) [56]. As a result, chlorophyte numbers may increase in the water between macrophyte stems [50].

The compositions of algae living on different macrophytes can vary considerably [56-57]. Our findings indicated that light conditions followed by substrate instability due to wave actions appear to be the main drivers of spatial and temporal variations of epipelon. Although some previous studies have reported that epiphytic algae displayed substrate selection, others indicated that they did not. Macrophytes with different morphological characteristics can naturally host different epiphytic communities [50]. In the present study, the species composition of submergent and emergent macrophytes differed, suggesting that the epiphytic algae in the lake displayed substrate selection. Emergent macrophytes (reed beds) surround the area around Gala, with colonies of $C$. demersum and M. spicatum spread in front of these macrophytes. Although Letáková et al. reported that Potamogeton gramineus is distributed along lake shores [10], in our study area P. crispus spreads out towards the centre of the lake, usually in the lake, far from the coastal areas. The epiphytic species composition of $P$. crispus was least similar to that of the other macrophyte species studied. This finding may explain the higher number of planktonic origins algae found on P. crispus as compared to on the other macrophyte species.

Throughout the study period, the numbers of $C$. placentula, A. constricta, and E. silesiacum on C. demersum were consistently high. In addition, the abundance of the green alga Spirogyra maxima and diatom Amphora ovalis was high on this macrophyte species in the summer months, whereas $S$. tetras was common in autumn. In the 
study, diatoms - especially $C$. solea, $C$. placentula, and G. acuminatum - were dominant on M. spicatum, and high numbers and biovolumes of the blue-green alga $A$. constricta were detected. High numbers of $M$. varians were also detected on M. spicatum in spring and summer. Among the three macrophyte species studied, the density of $P$. crispus was lowest. The numbers of $C$. placentula, $G$. parvulum, O. limosa, and A. constricta were high in all the samples. High numbers of Scenedesmus quadricauda and Planktolyngbya contorta were found on $P$. crispus, especially in spring, and high numbers of the diatoms Cymbella cistula, Phacus acuminatus, a planktonic euglenoid, and Closterium lunula (belonging to Charophyta), were found in summer. In common with the other macrophyte species, Epithemia sorex was the dominant species of epiphytic flora on P. crispus in the autumn.

Nutrient concentrations reduce the richness of algae species in aquatic environments. Some species can utilize these nutrients more rapidly than others, and these species exhibit faster growth rates. However, the present study did not reveal any significant association between nutrient levels and species richness. Species richness is generally derived from diversity calculations. In the present study, nutrient levels did not have a significant effect on biodiversity, as shown by the Shannon-Weaver biodiversity index, but the sampling month significantly affected community diversity. Diversity readings ranged from 1.006 to 1.427 ; typical ecological diversity levels do not exceed $4[58,59]$. In the present study, the algae community can be considered to have a heterogeneous species composition due to the habitat complexity of the submerged macrophytes.

The species richness and diversity values of the epiphytic algae detected in Gala Lake increased from late spring to mid-summer, with no significant differences determined among the algae associated with the three macrophyte species. In the present study, high turbidity, extensive spreading by phytoplankton, and macrophytes (which compete with periphyton for nutrients and light during summer months) may have restricted the growth of the epiphytic algae [60]. Biodiversity was previously reported to be positively correlated with high-quality water [52]. Although physico-chemical dynamics and competition affect species diversity, other factors, such as interactions of bacteria, protozoa and grazers, in addition to physical disturbances as a result of human activities, should also be considered [61].

Zhang et al. reported a positive correlation between Gomphonema and dissolved oxygen levels, and Stevenson et al. reported a correlation between relative abundance of Gomphonema and $\mathrm{pH}$ [62-63]. In a study by Liu et al., Gomphonema showed a strong relationship with various physico-chemical parameters such as $\mathrm{pH}$, dissolved oxygen, total nitrogen, and total phosporus [6263]. In the present study, the results were similar to the CCA results. Other studies (by Blinn and Herbst, Miranda and Krishnakumar) reported a similar relationship of temperature with Epithemia and Anabaena [64-65]. The
CCA revealed a significant correlation between water quality parameters and temporal changes in the dominant epiphytic algae [64]. In the present study, as revealed by the CCA, nitrogen compounds, dissolved oxygen levels, and $\mathrm{pH}$ in the spring; light transmission in June and July; and temperature, conductivity, and phosphate levels in August and September affected the colonization of epiphytic algae. Water transparency generally has direct ecological effects on littoral diatoms and is also used as an indication that reflects on other environmental parameters. Water transparency, which is inversely related to pollution gradient and conductivity, is in particular one of the important parameters determining the diatom assemblages in aquatic ecosystems $[60,66]$. It is generally stated that there is a relationship between epiphytic algae and environmental variables, and submerged macrophytes have been recommended for routine monitoring [67]. We found a significant relationship with selected environmental variables in congruence with other studies $[13,52]$. Increased numbers of submerged macrophytes and increased length resulted in overshadowing, which may have suppressed the development of some species. In an ecosystem, the aforementioned may benefit species that require relatively less light.

\section{Conclusions}

Temperature and water level were the main determinants of the seasonal variations in physical, chemical, and biological parameters. Hydrological pulses were the most important determinant of the epiphytic algae community. Substrate type affected algae epiphyte colonization in different seasons. The species composition of the epiphytic algae was diverse as a result of macrophyte morphology. However, the diversity values of the three submerged macrophyte species were similar.

\section{Acknowledgements}

The author would like to thank the Republic of Turkey Ministry of Forestry and Water Affairs, the General Directorate of Nature Conversation and National Parks, and Area I Edirne branch managers and their staff. The author would like to thank Prof. Dr. Meriç Albay for patience, advice, and valuable comments.

\section{References}

1. PELICICE F.M., THOMAZ S.M., AGOSTINHO A.A. Simple relationships to predict attributes of fish assemblages in patches of submerged macrophytes. Neotropical Ichthyology, 6 (4), 543, 2008.

2. PADIAL A.A., THOMAZ S.M., AGOSTINHO A.A. Effects of structural heterogeneity provided by the floating macrophyte Eichhornia azurea on the predation efficiency and habitat use of the small Neotropical fish Moenkhausia sanctaefilomenae. Hydrobiologia, 624 (1), 161, 2009. 
3. VADEBONCOEUR Y., STEINMAN A.D. Periphyton function in lake ecosystems. The Scientific World Journal, 29 (2), 1449, 2002.

4. STEINMAN A., ABDIMALIK M., OGDAHL M.E., OUDSEMA M. Understanding planktonic vs. benthic algal response to manipulation of nutrients and light in a eutrophic lake. Lake and Reservoir Management, 32 (4), 402, 2016.

5. CHAMBERS P.A., LACOUL P., MURPHY K. J., THOMAZ S.M. Global diversity of aquatic macrophytes in freshwater. Hydrobiologia 595 (1), 9, 2008.

6. CATTANEO A., GALANTI G., GENTINETTA S., ROMO S. Epiphytic algae and macro invertebrates on submerged and floating-leaved macrophytes in an Italian lake. Freshwater Biology, 39 (4), 725, 1998.

7. POMAZKINA G., KRAVTSOVA L., SOROKOVIKOVA E. Structure of epiphyton communities on Lake Baikal submerged macrophytes. Limnological Review, 12, 19, 2012.

8. NEIF É.M., BEHREND R.D.L., RODRIGUEZ L. Seasonal Dynamics of the structure of epiphytic algal community on different substrates from a Neotropical floodplain. Brazilian Journal of Botany, 36, 169, 2013.

9. LETÁKOVÁ M., CANTONATI M., HAŠLER P., NICOLA A., POULÍČKOVÁ A. Substrate specificity and fine-scale distribution of epiphytic diatoms in a shallow tarn in the Brenta Dolomites (south-eastern Alps). Plant Ecology and Evolution, 149, 144, 2016.

10. WIKLUND J.A., BOZINOVSKI N., HALL R.I., WOLFE B.B. Epiphytic diatoms as flood indicators. Journal of Paleolimnology, 44, 25, 2010.

11. GAISER E.E., SCINTO L.J., RICHARDS J.H., JAYACHANDRAN K., CHILDERS D.L., TREXLER J.C., JONES R.D. Phosphorus in periphyton mats provides the best metric for detecting low-depth P enrichment in an oligotrophic wetland. Water Research, 38, 507, 2004.

12. ALBAY M., AKÇAALAN R. Effects Of Water Quality And Hydrologic Drivers On Periphyton Colonization On Sparganium Erectum In Two Turkish Lakes With Different Mixing Regimes, Environmental Monitoring and Assessment, 146, 171, 2008.

13. YANG H., FLOWER R.J. Effects of light and substrate on the benthic diatoms in an oligotrophic lake, a comparison between a natural and artificial substrates, Journal of Phycology, 48, 1166, 2012.

14. FOREHEAD H.I., THOMPSON P.A. Microbial communities of subtidal shallow sandy sediments change with depth and wave disturbance, but nutrient exchanges remain similar. Marine Ecology Progress Series, 414, 11, 2010.

15. VADEBONCOEUR Y., DEVLIN S.P., MCINTYRE P.B, VANDER ZANDEN M.J. Is there light after depth? Distribution of periphyton chlorophyll and productivity in lake littoral zones. Freshwater Science, 33 (2), 524, 2014.

16. FOREHEAD H.I., KENDRICK G.A., THOMPSON P.A. Effects of shelter and enrichment on the ecology and nutrient cycling of microbial communities of subtidal carbonate sediments. FEMS Microbiology Ecology, 80, 64, 2012.

17. VIS C., HUDON C., CARIGNAN R. GAGNON P. Spatial analysis of production by macrophytes, phytoplankton and epiphyton in a large river system under different water-level conditions. Ecosystems, 10 (1), 293, 2007.

18. ANONYMOUS. Environment Status Report of Edirne Province. Edirne Valiliği, Çevreve Şehircilik İl Müdürlüğü 2012. [In Turkish].

19. ELIPEK B.Ç., ARSLAN N., KIRGIZ T., ÖTERLER B., GÜHER H., ÖZKAN N. Analysis of Benthic
Macroinvertebrates in Relation to Environmental Variables of Lake Gala, a National Park of Turkey. Turkish Journal of Fisheries and Aquatic Sciences, 10 (1), 235, 2010.

20. TOKATLI C. Drinking Water Quality of a Rice Land in Turkey by a Statistical and GIS Perspective, İpsala District. Polish Journal of Environmental Studies, 23 (6), 2247, 2014

21. TOKATLI C. Assessment of the Water Quality in the Meriç River, As an Element of the Ecosystem in the Thrace Region of Turkey. Polish Journal of Environmental Studies, 24 (5), 2205, 2015.

22. NOGES N., LUUP H., FELDMANN T. Primary production of aquatic macrophytes and their epiphytes in two shallow lakes (Peipsi and Vortsjarv) in Estonia. Aquatic Ecology, 44, 83, 2010.

23. BENNION H., KELLY M.G., JUGGINS S., YALLOP M.L, BURGESS A, JAMIESON J., KROKOWSKI J. Assessment of ecological status in UK lakes using benthic diatoms. Freshwater Science, 33 (2), 639, 2015.

24. BLANCO S., CEJUDO-FIGUEIRAS C., ÁLVAREZBLANCO I., VAN DONK E., GROSS E.M., HANSSON L.A., IRVINE K., JEPPENSEN E., KAIRESALO T., MOSS B., NÕGES T. BÉCARES E. Epiphytic diatoms along environmental gradients in western european shallow lakes. Clean soil air water, 42 (3), 229, 2014.

25. KING L., CLARKE G., BENNION H., KELLY M.G., YALLOP M.L. Recommendations for sampling littoral diatoms in lakes for ecological status assessments. Journal of Applied Phycology, 18, 15-25, 2006.

26. SZLAUER-LUKASZEWSKA, A. Succession of periphyton developing on artificial substrate immersed in polysaprobic wastewater reservoir. Polish Journal of Environmental Studies, 16 (5), 753, 2007.

27. CEN (Comité Européen de Normalisation). Water qualityGuidance standard for the identification, enumeration and interpretation of benthic diatom samples from running waters. EN 14407:2004. Comité Européen de Normalisation, Geneva, Switzerland, 2004.

28. UTERMÖHL H. Zur Vervollkommnung der quantitativen Phytoplankton Methodik. Mitteil. Verhandlungen der Internationalen Vereinigung für Theoretische und Angewandte Limnologie, 9, 1, 1958.

29. LANGE-BERTALOT H., BAK M., WITKOWSKI A., TAGLIAVENTI N. Diatoms of Europe. -In: Lange-Bertalot, H. (ed.): Eunotia and some related genera, A.R.G. Gantner Verlag K. G., Ruggel, 6, 747, 2011.

30. KOMAREK J., FOTT B. The internal waters. Volume 26, The phytoplankton of the freshwater. 7 part, 1st half, Chlorophyceae (green algae), order: Chlorococcales. E. Schweizerbart's publishing book. (Die binnnengewässer. Band 26, Das phytoplankton des süßwassers. 7 Teil, 1. Hälfte, Chlorophyceae (Grünalgen), Ordnung: Chlorococcales. E. Schweizerbart'sche Verlagsbuchhandlung), Stuttgart, 1, 1983 [In German]

31. KRAMMER K., LANGE-BERTALOT H. Bacillariophyceae. Part 1-4. Freshwater flora from middleeuropa. (Bacillariophyceae. 1-4 Teil. Süsswasserflora von Mitteleuropa). H. Ettl, J. Gerloff, H. Heynig, and D. Mollenhauer (editors). FischerVerlag, Stuttgart, Germany, 1986-2004 [In German].

32. KOMAREK J, ANAGNOSTIDIS K. Cyanoprokariota. 2. Teil: Oscillatoriales. In: Büdel B, Gärtner G, Krienitz L, Schagerl M(eds) Süßwasserflora von Mitteleuropa. Elsevier, Heidelberg, 2005.

33. HINDAK F. Colour Atlas of Cyanophytes. VEDA, Bratislava, 253, 2008. 
34. KRISTIANSEN J., PREISIG H.R. Phylum Chrysophyta (Golden Algae). In: The freshwater algal flora of the British Isles. An identification guide to freshwater and terrestrial algae. Second edition. (John, D.M., Whitton, B.A. \& Brook, A.J. Eds), Cambridge: Cambridge University Press 2011.

35. GUIRY M.D., GUIRY, G.M. AlgaeBase. World-wide electronic publication, National University of Ireland, Galway. http://www.algaebase.org; 2017. searched on 31 January 2017.

36. NUSCH E. Comparison of different methods for chlorophyll and phaeopigment determination. Archiv für Hydrobiologie -BeiheftErgebnisse der Limnologie, 14, 14-36. 1980.

37. APHA, AWWA, \& WEF. 10300 Periphyton. Standard Methods for the Examination of Water and Wastewater, $22^{\text {nd }}$ ed. American Public Health Association, Washington, D.C., 2012.

38. ROS J., Ecology Pratices (Práticas de ecologia). Barcelona, Editora Omega, 181, 1979 [In Portugese].

39. BICUDO C., MENEZES M. Genera of Brazilian freshwater algae (Gêneros de algas de águas continentais do Brasil. (Chave de identificação e descrições)). São Carlos, RIMA, 489, 2006 [In Portugese].

40. HILLEBRAND H., DÜRSELEN C., KIRSCHTEL D., POLLINGHER U., ZOHARY T. Biovolume calculation for pelagic and benthic microalgae. Journal of Phycology, 35 (2), 403, 1999.

41. SUN J., LIU D. Geometric models for calculating cell biovolume and surface area for phytoplankton. Journal of Plankton Research, 25 (11), 1331, 2003.

42. SPSS 22.0 IBM Corp. Released IBM SPSS Statistics for Windows, Version 22.0. Armonk, NY: IBM Corp., 2013.

43. ADDINSOFT, XLSTAT. Data analysis and statistics with MS Excel. Addinsoft, NY, USA. xlstat available at http:// www.xlstat.com/en/home, 2015.

44. BAYLEY S.E. WONG A.S., THOMPSON J.E. Effects of agricultural encroachment and drought on wetlands and shallow lakes in the boreal transition zone of Canada. Wetlands, 33 (1), 17, 2013.

45. HANSON M.A., HERWIG B.R., ZIMMER K.D, HANSELWELCH N. Rehabilitation of shallow lakes: time to adjust expectations? Hydrobiologia, 787 (1), 45, 2017.

46. NIVOLIANITOU Z., SYNODINOU B. Environmental Management of Big Riverine Floods: The Case of Evros River in Greece. Advances in Environmental Science and Sustainability, 5th Proceedings Book; 15, 2012.

47. GRAHAM L.E., GRAHAM M., WILCOX L.W. Algae. Prentice-Hall, Inc., Upper Saddle River, New Jersey. 616, 2009.

48. ÖTERLER B., ALBAY M., ÇAMUR ELIPPEK B., GÜHER H., KIRGIZ T. Spatial and temporal distribution of phytoplankton in Lake Gala (Edirne/TURKEY). Trakya University Journal of Natural Sciences, 16 (2), 71, 2015.

49. CANO M., CASCO M., CLAPS M. Effect of environmental variables on epiphyton in a Pampean lake with stable turbidand clear-water states. Aquatic Biology, 15 (1), 47, 2012.

50. MESSYASZ B., RYBAK A. The distribution of green algae species from the Enteromorpha genera [syn. Ulva; Chlorophyta] in Polish inland waters. Oceanological and Hydrobiological Studies, 38 (1), 121, 2009.

51. HÁJEK F., POULÍČKOVA A., VAŠUTOVÁ M., SYROVÁTKA V., JIROUŠEK M., ŠTEPÁNKOVÁ J., OPRAVILOVÁ V., HÁJKOVÁ P. Small ones and big ones: cross-taxon congruence reflects organism body size in ombrotrophic bogs. Hydrobiologia, 726, 95, 2014.

52. KOLLÁR J., FRÁNKOVÁ M., HAŠLER P., LETÁKOVÁ M., POULÍČKOVÁ A. Epiphytic diatoms in lotic and lentic waters-diversity and representation of species complexes. Fottea, 15, 259, 2015.

53. TUNCA H., ONGUN-SEVINDIKK T., BAL D.N., ARABACI S. Community structure of epiphytic algae on different macrophytes ar Acarlar floodplain forest (Northern Turkey). Chinese Journal of Oceanology and Limnology, 32 (4), 845, 2014.

54. CANO M.G., CASCO M.A., CLAPS M.C. Epipelon dynamics in a shallow lake through a turbid-and a clearwater regime. Journal of Limnology, 75 (2), 355, 2016.

55. HINOJOSA-GARRO D., MASON C.F., UNDERWOOD G.J.C. Influence of macrophyte spatial architecture on periphyton and macroinvertebrate community in shallow water bodies under contrasting management. Fundamentals of Applied Limnology, 177 (1), 19, 2010.

56. CANTONATI M., ANGELI N., BERTUZZI E., SPITALE D., LANGE-BERTALOT H. Diatoms in springs of the Alps: spring types, environmental determinants, and substratum. Freshwater Science, 31, 499, 2012.

57. CANO M.G., CASCO M.A., CLAPS M.C. Epipelon dynamics in a shallow lake through a turbid-and a clearwater regime. PAGEPress Publications, 2016.

58. FERNANDES U.L., DE OLIVEIRA E.C.C., LACERDA S.R. Role of macrophyte life forms in driving periphytic microalgal assemblages in a Brazilian reservoir. Journal of limnology, 75 (1), 44, 2016.

59. VERHULST S. Response of the Epiphytic Algal Communities to Experimentally Elevated Nutrient Levels in Intertidal Salt Marsh Habitats. M.Sc. Thesis, University of North Florida, USA, 435, 2013.

60. De NICOLA D.M., KELLY M. Role of periphyton in ecological assessment of lakes. Freshwater Science, 33, 619, 2014.

61. TRIEST L., LUNGAYIA H., NDIRITU G., BEYENE A. Epilithic diatoms as indicators in tropical African rivers (Lake Victoria catchment). Hydrobiologia, 695 (1), 343, 2012.

62. ZHANG N, FAN Y., LIU Y. Relationship between diatom communities and environmental conditions at Honghe wetland, China. African Journal of Biotechnology, 10 (76), 17506, 2011.

63. LIU Y., HUI H.K., SUN C.M., FAN Y.W. Using diatom assemblage to assess the water quality in Heilongjiang river (Heihe part). Frontiers of Energy and Environmental Engineering, Edited by Wen-Pei Sung, Jimmy C. M. Kao and Ran Chen, CRC Press, 55, 2012.

64. BLINN D., HERBST D. Use of diatoms and soft algae as indicators of environmental determinants in the Lahontan Basin, USA. Annual Report for California State Water Resources Board Contract Agreement 704558.01CT766. $-25+10$ pp., USA, 2003.

65. MIRANDA J., KRISHNAKUMAR G. Microalgal diversity in relation to the physicochemical parameters of some Industrial sites in Mangalore, South India. Environmental Monitoring and Assessment, 187 (11), 664, 2015.

66. FIDLEROVÁ D., HLÚBIKOVÁ D. Relationships between benthic diatom assemblages' structure and selected environmental parameters in Slovak water reservoirs (Slovakia, Europe). Knowledge and management of aquatic ecosystems, 417, 27, 2016.

67. HÁJKOVÁ P., BOJKOVÁ J., FRÁNKOVÁ M., OPRAVILOVÁ V., HÁJEK M., KINTROVÁ K., HORSÁK M. Disentangling the effects of water chemistry and substrastum structure on moss-dwelling unicellular and multicellular microorganisms in spring fens, Journal of Limnology, 1, 54, 2011. 